\title{
Growth and quality of Mollar pomegranate tree seedlings propagated by cuttings
}

\section{Crescimento e qualidade de mudas de romãzeira 'Molar' propagadas por estaquia}

\author{
Emanoela Pereira de Paiva ${ }^{1 *}$; Railene Hérica Carlos Rocha ${ }^{2}$; Francisco Hevilásio \\ Freire Pereira ${ }^{2}$; Francisco de Assis de Sousa ${ }^{3}$; Wellinghton Alves Guedes ${ }^{3}$; \\ Francisco Vanies da Silva Sá4; Inácia dos Santos Moreira ${ }^{5}$
}

\begin{abstract}
The seminiferous propagation of the pomegranate tree is dramatically affected by the presence of a sarcotesta, which often makes this method of propagation unfeasible. Therefore, the aim of this study was to evaluate the production of rootstocks for Mollar pomegranate cuttings under different management techniques in the dry and wet seasons. Two experiments were performed, one in the dry season (August to December 2012, Experiment I), and another in the rainy season (January to June 2013, Experiment II). The experiments used a completely randomized design with four replications and five seedlings per plot. To monitor plant growth and physiology, a factorial scheme using two factors, management of softwood cuttings (cuttings with leaves; cuttings without leaves; and cuttings without leaves, but with an incision at the base) and evaluation times $(60,70,80,90$, and 100 days after planting [DAP] in Experiment I and 60, 70, 80, 90, 100, 110, 120, 130, 140, and 150 DAP in Experiment II) was adopted. The propagation material was collected from commercial plants, from the median portion of the branch. The cuttings were approximately $15 \mathrm{~cm}$ long. Cuttings without leaves with an incision at the base were more suitable for vegetative propagation of Mollar pomegranate trees, regardless of season (dry or wet). Seedlings grown in the rainy season had higher survival rates and higher root and shoot growth. The use of cuttings with leaves for the vegetative propagation of the Mollar pomegranate tree in the dry season is not feasible. The best time to transplant Mollar pomegranate tree seedlings, in the rainy season, is at 130 DAP, at an average height of $45 \mathrm{~cm}$.
\end{abstract}

Key words: Punica granatum L., vegetative propagation, seedling production

\section{Resumo}

A propagação seminífera da romãzeira é drasticamente afetada pela presença da sarcotesta na semente, que muitas vezes chegando a inviabilizar esse método de propagação. Com isso, objetivou-se avaliar a produção de porta-enxerto sob diferentes técnicas de manejo de estacas de romãzeira 'Molar', nos

\footnotetext{
1 Eng $^{\mathrm{a}} \mathrm{Agr}^{\mathrm{a}}$, Discente do Curso de Doutorado em Fitotecnia, Universidade Federal Rural do Semi-Árido, UFERSA, Mossoró, RN, Brasil. E-mail: emanuelappaiva@hotmail.com

2 Profs., Drs. em Fitotecnia, Universidade Federal de Campina Grande, UFCG, Pombal, PB, Brasil. E-mail: raileneherica@ccta. ufcg.edu.br; fhfpereira@ccta.ufcg.edu.br

3 Eng $^{\text {os }}$ Agr $^{\text {os }}$, Universidade Federal de Campina Grande, UFCG, Pombal, PB, Brasil. E-mail: franciscoufcg@gmail.com; wellinghton_guedes@hotmail.com

4 Eng $^{\mathrm{o}} \mathrm{Agr}^{\mathrm{o}}$, Discente do Curso de Mestrado em Manejo de Solo e Água, Universidade Federal Rural do Semi-Árido, UFERSA, Mossoró, RN, Brasil. E-mail: vanies_agronomia@hotmail.com

5 Tecnóloga em Alimentos, Discente do Curso de Doutorado do Programa de Pós-Graduação em Engenharia Agrícola, UFCG, Campina Grande, Paraíba, Brasil. E-mail: inaciamoreira@ymail.com

* Author for correspondence
} 
períodos seco e chuvoso. Realizaram-se dois experimentos, um no período seco, de agosto a dezembro de 2012 (Experimento I) e outro no período chuvoso, de janeiro a junho de 2013 (Experimento II). Os experimentos foram em delineamento inteiramente casualizado, com quatro repetições e cinco mudas por parcela. Para o acompanhamento do crescimento e fisiologia da planta adotou-se esquema fatorial composto por dois fatores, manejos de estacas semilenhosas (estacas com folhas; estacas sem folhas e estacas sem folhas mais incisão na base) e épocas de avaliação $(60,70,80,90$ e 100 dias após o plantio - DAP no experimento I e 60, 70, 80, 90, 100, 110, 120, 130, 140 e 150 DAP no experimento II). O material propagativo foi retirado de plantas comerciais, da porção mediana do ramo. As estacas foram padronizadas com aproximadamente $15 \mathrm{~cm}$ de comprimento. Estacas sem folhas com incisão na base foram mais adequadas para a propagação vegetativa da romãzeira 'Molar' independentemente do período do ano (seco ou chuvoso). Mudas produzidas no período chuvoso apresentaram maior índice de sobrevivência, e crescimento da parte aérea e radicular. O uso de estacas com folhas para a propagação vegetativa da romãzeira 'Molar' no período seco é inviável. A melhor época para o transplantio das mudas de romãzeira 'Molar', no período chuvoso, é aos 130 dias após o plantio, e apresentam uma altura média de $45 \mathrm{~cm}$.

Palavras-chave: Punica granatum L., propagação vegetativa, produção de mudas

\section{Introduction}

The pomegranate tree (Punica granatum L.) has drawn the attention of many fruit tree producers, and production has increased rapidly from small orchards to large areas of cultivation; production increased from $185 \mathrm{t}$ of fresh fruit in 2001 to 2030 $t$ in 2011 (IBRAF, 2011). Due to the expansion of the cultivated area of the pomegranate tree, new technologies that provide good seedling production have been sought, since the use of high-quality seedlings in orchard implementation promotes increased productivity and an early first crop (PRADO et al., 2005).

Several vegetative propagation techniques are currently used, but the one that stands out is propagation by cuttings, in which plant segments, under suitable conditions, grow roots and produce a new plant identical to the plant of origin (CHAGAS et al., 2008; PIO et al., 2007). During seedling production, factors such as cultivar, stage of development, substrate, growth regulators, in addition to different environmental conditions inherent to the season, can interfere in the rooting process (BIAZATTI, 2013). Ramos et al. (2008) observed that fig tree cuttings (Ficus carica L.), when collected in the fall, show a 55\% reduction in rooting. According to Scaloppi Júnior \& Martins (2003), collecting cuttings at the optimal time of year can improve adventitious rooting.
Few reports have been published on propagation of pomegranate trees by cuttings, and all of these report on the use of cuttings without leaves (BATISTA et al., 2011). Thus, the goal of this study was to evaluate different cutting management techniques for the vegetative propagation of the Mollar pomegranate tree in the dry and rainy seasons.

\section{Material and Methods}

The survey was conducted in a greenhouse at the Agrifood Science and Technology Center of the Federal University of Campina Grande, in Pombal, PB, Brazil. Two experiments were performed, one in the dry season, from August to December 2012 (Experiment I), and another in the rainy season, from January to June 2013 (Experiment II). The city of Pombal is located at $6^{\circ} 46^{\prime} 13^{\prime \prime} \mathrm{S}$ and $37^{\circ} 48^{\prime} 06^{\prime \prime}$ $\mathrm{W}$, at an altitude of $144 \mathrm{~m}$. According to the Köppen classification, the local climate is semi-arid ("AW" hot and humid) with an average annual rainfall and temperature of $431.8 \mathrm{~mm}$ and $28^{\circ} \mathrm{C}$, respectively.

The Mollar variety of pomegranate tree was used, and the propagation material was purchased from a commercial orchard of the Águas de Tamanduá Farm, located in the Sousa wetlands, in Sousa, PB, Brazil ( $38^{\circ} 13^{\prime} 41^{\prime \prime} \mathrm{S}$ and $\left.06^{\circ} 45^{\prime \prime} 33^{\prime \prime} \mathrm{W}\right), 30 \mathrm{~km}$ from the city of Pombal, PB. Cuttings were taken from 
the softwood of the median portion of the branch, from 3-year-old pomegranate trees that had been propagated by seed and managed under an organic system (IBD Certificate, Law 10.831).

The cuttings were obtained from vigorous and healthy plants in the morning, using pruning shears. Next, they were placed in a polystyrene box, between layers of moistened paper towel to prevent dehydration. Subsequently, they were transported to the Plant Science Laboratory of the Federal University of Campina Grande, Pombal, PB.

In the laboratory, the cuttings were washed with tap water and sterilized with a $2 \%$ sodium hypochlorite solution for 5 minutes, and cuttings of a standard size (a length of $15 \mathrm{~cm}$ and a diameter of 4-5 mm) were selected.
Next, the cuttings were divided into the following four management (M) groups: M1, cuttings with leaves three to four pairs of leaves were left per cutting, being cut at the middle portion of their length in order to reduce leaf dehydration; M2, cuttings without leaves all leaves were removed from the cuttings, taking care to avoid damaging buds; M3, cuttings without leaves, but with an incision at the base all leaves were removed from the cuttings, and then two bevel incisions were made at the base, at approximately $1 \mathrm{~cm}$ length and 2-3-mm deep.

Cuttings were planted by burying the bottom third in $20 \mathrm{~cm} \times 25 \mathrm{~cm}$ polyethylene bags containing a substrate composed of three parts washed sand: 1/2 substrate $\left(\right.$ Plantmax $\left.^{\circledR}\right)$ : 1/2 cattle manure. The chemical and physical properties of the substrate were analyzed in the Soil and Plant Nutrition Laboratory (LSNP/CCTA) (Table 1).

Table 1. Chemical analysis and physical of substrate used for the production of pomegranate seedlings. UFCG, Pombal - PB, 2014.

\begin{tabular}{|c|c|c|c|c|c|c|c|c|c|c|c|c|}
\hline \multicolumn{13}{|c|}{ Chemical analysis * } \\
\hline $\mathrm{pH}$ & $\mathrm{CE}$ & $\mathrm{N}$ & & $\mathrm{P}$ & $\mathrm{K}$ & $\mathrm{Ca}$ & $\mathrm{Mg}$ & $\mathrm{Na}$ & $\mathrm{T}$ & $\mathrm{V}$ & PST & O.M. \\
\hline- & $-\mathrm{dS} \mathrm{m} \mathrm{m}^{-1}-$ & $-\%-$ & & $\mathrm{g} \mathrm{dm}^{-3}-$ & \multicolumn{5}{|c|}{--------------------cmol dm³'----------- } & \multicolumn{2}{|c|}{------\%"------ } & $-\mathrm{g} / \mathrm{kg}-$ \\
\hline 7.7 & 0.8 & 2.1 & & 10 & 2.2 & 5.6 & 5.8 & $1.1 \quad 13.6$ & 14.7 & 92.6 & 7.4 & 41 \\
\hline \multicolumn{13}{|c|}{ Physical analysis $* *$} \\
\hline Areia & Silte & \multicolumn{2}{|c|}{ Argila } & \multicolumn{3}{|c|}{ Densidade aparente } & \multicolumn{2}{|c|}{ Densidade real } & \multicolumn{2}{|c|}{ Porosidade total } & \multicolumn{2}{|c|}{ Classe textural } \\
\hline \multicolumn{4}{|c|}{-----------g Kg Kg-1--------- $^{-1}$} & \multicolumn{5}{|c|}{ 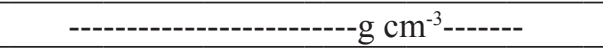 } & \multicolumn{2}{|c|}{$\mathrm{m}^{-3} \mathrm{~m}^{-3}$} & \multicolumn{2}{|c|}{-} \\
\hline 723 & 151 & \multicolumn{2}{|c|}{126} & \multicolumn{3}{|c|}{1.15} & \multicolumn{2}{|c|}{2.41} & \multicolumn{2}{|c|}{0.52} & \multicolumn{2}{|c|}{ Franco Arenoso } \\
\hline
\end{tabular}

Analytical laboratory: Soil Laboratory and Plant Nutrition - LSNP, Pombal - PB. * pH in water, $\mathrm{KCl}$ and CaCl2 - Ratio 1: 2.5; P, K, Na: Mehlich I; Al, Ca, Mg: KCL extractor - $1 \mathrm{~mol} / \mathrm{L}$; SB = Basic Sum exchangeable; C.E. in water - ratio 1: 2.5; CTC (T) - Cation Exchange Capacity at pH 7.0; V = Base Saturation Index; PST = exchangeable sodium percentage. ** Particle size: at decimeter bouyoucos, bulk density: Method of $100 \mathrm{ml}$ beaker; Actual density: balloon method.

The seedlings were cultivated in a greenhouse with netted shade coverage to allow 50\% light passage. A daily log of temperature and relative humidity was kept using a digital thermo hygrometer
(Figures 1 and 2). Soil was irrigated once per day to keep the soil moisture close to maximum field capacity, based on the weighing method, replacing any water that evaporated the previous day. 
Figure 1. Weather averages $\left(\mathrm{T}^{\circ} \mathrm{C}\right)(\mathrm{A})$ and relative humidity $(\% \mathrm{U})(\mathrm{B})$ in a greenhouse during the period from September 7 to 14 December 2012. UFCG, Pombal-PB, 2014.

A

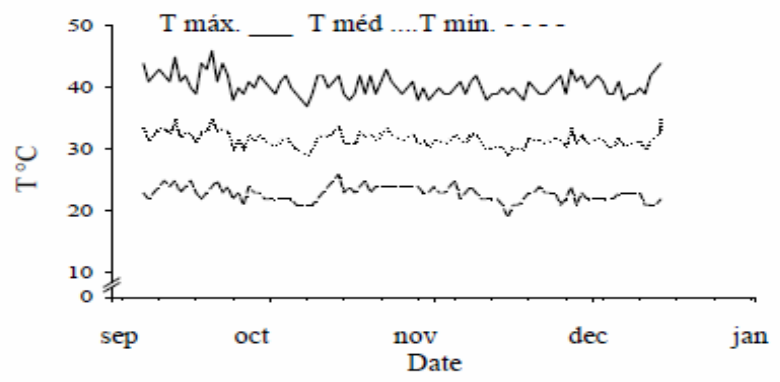

B

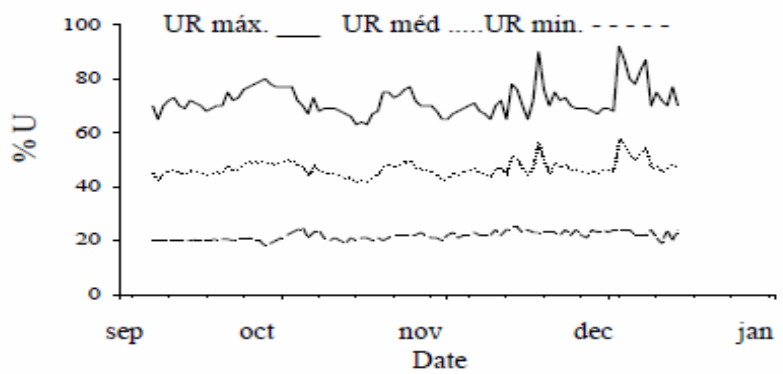

Figure 2. Weather averages $\left(\mathrm{T}^{\circ} \mathrm{C}\right)(\mathrm{A})$ and relative humidity $(\% \mathrm{U})(\mathrm{B})$ in a greenhouse during the period from April 14 to June 14. UFCG, Pombal-PB, 2014.

A

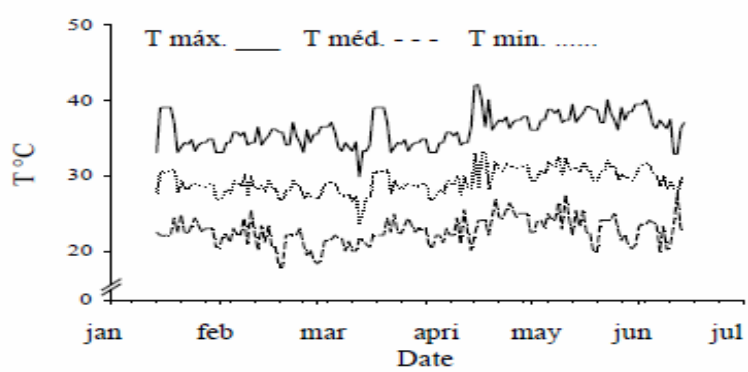

Experiment I (dry season)

The experiment used a completely randomized design (CRD), with four replications and five seedlings per replication, using a factorial scheme $(3 \times 5)$, with treatments consisting of cutting management (M1, cuttings with leaves; M2, cuttings without leaves; and M3, cuttings without leaves with an incision at the base) $\times$ evaluation time (days after planting, DAP).

At 60, 70, 80, 90, and $100 \mathrm{DAP}$, survival rate, number of shoots, number of leaves, cutting diameter, and shoot length were assessed. Physiological analysis of $\mathrm{CO}_{2}$ uptake, transpiration, stomatal conductance, internal $\mathrm{CO}_{2}$ concentration, water use efficiency, and the instantaneous efficiency of carboxylation were performed from 70 DAP, using a $3 \times 4$ factorial scheme for cutting management $\times$ evaluation time.
B

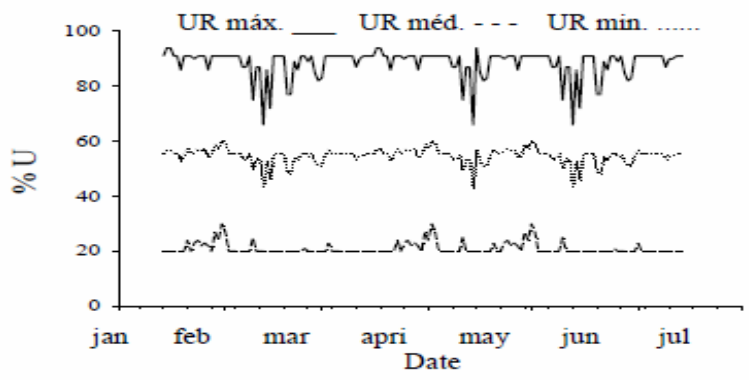

Destructive analyses were conducted at 100 DAP, to determine root length, shoot and root fresh weight, total dry weight, shoot and root dry weight, and the Dickson quality index.

\section{Experiment II (rainy season)}

The experiment used a CRD with four replications and five seedlings per replication. For the nondestructive variables, we used a $3 \times 10$ factorial scheme of cutting management $\times$ evaluation time.

At $60,70,80,90,100,110,120,130,140$, and $150 \mathrm{DAP}$, the same non-destructive analyses mentioned in Experiment I were performed. Physiological analyses of $\mathrm{CO}_{2}$ uptake, transpiration, stomatal conductance, internal $\mathrm{CO}_{2}$ concentration, water use efficiency, and instantaneous efficiency of carboxylation were performed from 90 DAP (at 
$90,120,130,140$, and 150 DAP) using a factorial scheme $(3 \times 5)$, cutting management $\times$ evaluation time.

Destructive analyses were performed at 150 DAP, to determine root length, shoot and root fresh weight, total dry weight, shoot and root dry weight, and the Dickson quality index.

\section{Characteristics evaluated}

During the experiments, the following parameters were evaluated: survival rate (SR), the number of living seedlings vs. the total number of seedlings; number of shoots (NS), the number of shoots emerged; leaf number (LN), leaves larger than $3 \mathrm{~cm}$; shoot length (SL) (cm) and root length $(\mathrm{RL})(\mathrm{cm})$, measured from the plant neck to the root apex; cutting diameter (CD) (mm), determined by measuring the middle portion of the cutting using a digital caliper; shoot fresh weight (SFW) (g per plant) and root fresh weight (RFW) (g per plant), measured by weighing on an analytical scale; shoot dry weight (SDW) (g per plant), root dry weight (RDW) (g per plant), and total dry weight (TDW) (g per plant). Samples were dried in an air circulation oven at $60^{\circ} \mathrm{C}$ until they reached a constant weight, and then weighed using an analytical scale accurate to $0.01 \mathrm{~g}$. To determine the Dickson quality index (DQI), the following equation, which uses morphological variables such as TDW, SDW, RDW, SL, and CD (CRUZ et al., 2006), was used:

$$
D Q I=\frac{\mathbf{T D W}(\mathbf{g})}{\frac{\mathbf{S L}(\mathbf{c m})}{\mathbf{D C}(\mathbf{m m})}+\frac{\mathbf{S D W}(\mathbf{g})}{\operatorname{RDW}(\mathbf{g})}}
$$

Throughout the experiments, gas exchange in fully developed leaves was also determined, from 7:00 to 8:00 am. The rates of $\mathrm{CO}_{2}$ uptake (A) $\left(\mu \mathrm{mol} \cdot \mathrm{m}^{-2} \cdot \mathrm{s}^{-1}\right)$, transpiration $(E)(\mathrm{mmol} \mathrm{de}$

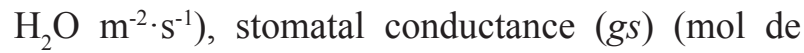
$\mathrm{H}_{2} \mathrm{O} \mathrm{m} \mathrm{m}^{-2} \cdot \mathrm{s}^{-1}$ ), and internal $\mathrm{CO}_{2}$ concentration $(\mathrm{Ci})$ $\left(\mu \mathrm{mol} \cdot \mathrm{m}^{-2} \cdot \mathrm{s}^{-1}\right)$ were determined. Using these data, water use efficiency (WUE) $(A / T)\left[\left(\mu \mathrm{mol} \cdot \mathrm{m}^{-2} \cdot \mathrm{s}^{-1}\right)\right.$ $\left.\left(\mathrm{mol} \mathrm{H} \mathrm{O} \mathrm{m}^{-2} \cdot \mathrm{s}^{-1}\right)^{-1}\right]$ and carboxylation instantaneous efficiency $\Phi c(\mathrm{~A} / \mathrm{Ci})$ (KONRAD et al., 2005) were quantified. These measurements were conducted using a portable photosynthesis measurement tool, the LCPro+ by ADC Bio Scientific Ltd., with a constant light source of $1,200 \mu \mathrm{mol} \cdot$ photons $\cdot \mathrm{m}^{-2} \cdot \mathrm{s}^{-1}$ and a $\mathrm{CO}_{2}$ concentration of $370 \mu \mathrm{mol} \cdot \mathrm{mol}^{-1}$.

\section{Statistical analyses}

The data were interpreted by analysis of variance (ANOVA). Qualitative variables were compared using Tukey's test at $5 \%$ probability, and quantitative variables were compared using regression analysis. The analyses were performed using the software Sistema para Análise de Variância - SISVAR (FERREIRA, 2011).

\section{Results and discussion}

\section{Experiment I (dry season)}

The survival rate was higher in the cuttings planted without leaves with an incision at the base (M3), significantly differing from the remaining management techniques. The M3 group showed $70 \%$ survival, whereas the M1 and M2 groups showed $52.65 \%$ and $30 \%$ survival, respectively (Table 2). 
Table 2. Survival percentage (SR), number of shoots (NS), number of leaves (LN), cutting diameter (DC) and shoot length (SL) in pomegranate seedlings 'Molar' due to the handling of stakes in the period dry the year (AugustDecember). UFCG, Pombal-PB, 2014.

\begin{tabular}{cccccc}
\hline Manejos* $^{*}$ & SR $(\%)$ & NS & LN & DC $(\mathrm{mm})$ & SL $(\mathrm{cm})$ \\
\hline M1 & $30.00 \mathrm{c}$ & $1.75 \mathrm{~b}$ & $62.12 \mathrm{~b}$ & $5.62 \mathrm{~b}$ & $15.86 \mathrm{~b}$ \\
M2 & $52.65 \mathrm{~b}$ & $2.62 \mathrm{a}$ & $72.03 \mathrm{~b}$ & $7.83 \mathrm{a}$ & $13.46 \mathrm{~b}$ \\
M3 & $70.00 \mathrm{a}$ & $2.48 \mathrm{a}$ & $115.95 \mathrm{a}$ & $8.01 \mathrm{a}$ & $29.61 \mathrm{a}$ \\
\hline
\end{tabular}

Means followed by the same lower case letter in the column do not differ at $5 \%$ probability by Tukey test. * M1: Cuttings with leaves; M2: Cuttings without leafless; M3: Cuttings with leaves and incision in the stake base.

Thus, cuttings in the M3 group showed higher viability, due to the higher survivability of the species in the harsh conditions of the dry season, when temperatures are very high and relative humidity is very low (Figure 2). From a physiological point of view, cuttings with an incision at the base show greater water and nutrients absorption, increasing rooting efficiency (SANTORO et al., 2010).

The M2 and M3 groups showed similar numbers of shoots and cutting diameter, and both groups were on average higher than the M1 group (Table 2). Thus, removing leaves from cuttings influences these characteristics. The removal of the leaves may have prevented dehydration of the cuttings and stimulated the emergence of shoots, which were more exposed to environmental conditions, favoring lighting in the shoots, located in the leaf axils. Hussain et al. (2012) also observed that different types of pomegranate tree cuttings showed differences in diameter increase. In contrast, Batista et al. (2011), studying the vegetative propagation of pomegranate trees on different substrates, found that treatments did not differ significantly in stem diameter characteristics.

Concordant with the results for other variables, the M3 technique produced better results for the number of emerged leaves and shoot length, significantly differing from the other techniques, which did not differ (Table 2). The poorer performance of cuttings with leaves may be related to their dehydration sensitivity under dry season conditions (Figure 1), since they lost their leaves at 2 DAP.

Batista et al. (2011), while studying the vegetative propagation of pomegranate trees by cuttings in different substrates, observed no significant differences in the number of leaves; the average number of leaves ranged from 29.5 to 37.25 at 60 DAP.

Linear increases were observed in number of leaves, cutting diameter, and shoot length (Figures $3 \mathrm{~A}, \mathrm{~B}$, and C). An increase in the number of leaves is highly beneficial, as leaves are the primary site of photosynthesis, act as reserve centers, and are a source of auxins and rooting cofactors that are translocated to the bases of cuttings (VIDAL et al., 2006). The mean diameter of the cuttings increased from $6.7 \mathrm{~mm}$ at $60 \mathrm{DAP}$ to $7.5 \mathrm{~mm}$ at $100 \mathrm{DAP}$ (Figure 3B). Altoé et al. (2011) found similar effects in the guava tree; they observed a gradual increase in the average diameter of the cuttings as the seedlings developed. 
Figure 3. Effect of evaluation times in the variables: number of leaves (LN), cutting diameter (DC) and shoot length (SL) in pomegranate seedlings 'Molar' due to the handling of stakes in the period dry the year (August-December). UFCG, Pombal-PB, 2014.

A

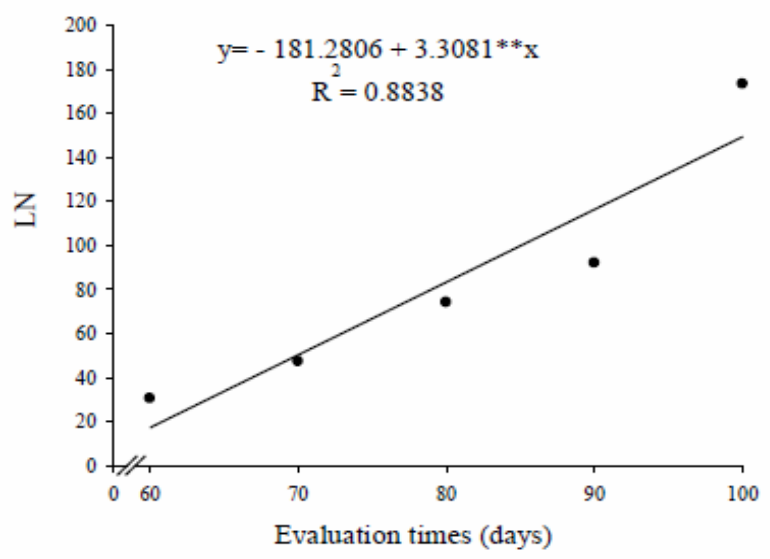

B

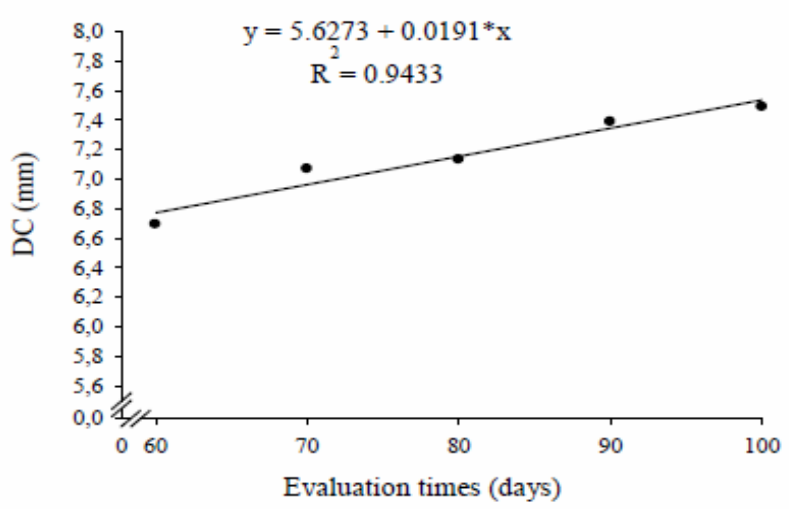

$\mathrm{C}$

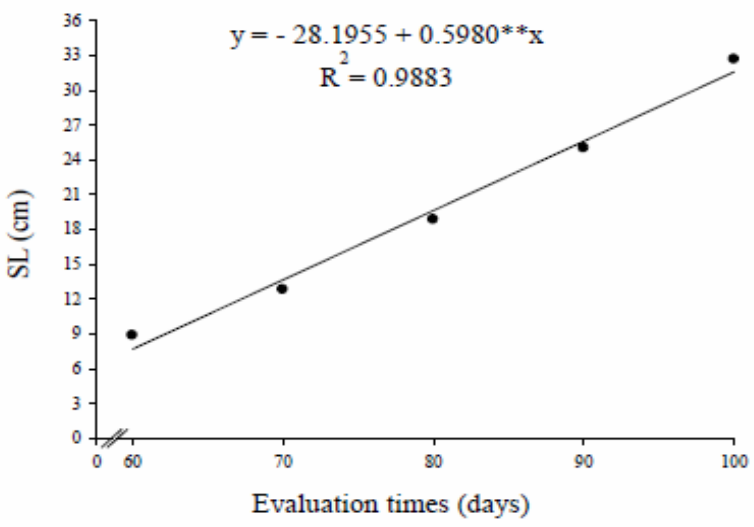

** Significant at $1 \%$ by ' $t$ ' Student test.

Shoot length increased, on average, from $9 \mathrm{~cm}$ at 60 DAP to $33 \mathrm{~cm}$ at $100 \mathrm{DAP}$, for an average increase of $24 \mathrm{~cm}$, concordant with the results reported by Marm (2010), who reported that the Mollar variety is very vigorous and shows rapid growth.

The M3 group showed an increase in root length $(34.85 \mathrm{~cm})$, differing from the other techniques (M1 and M2), in which no significant differences were observed (Table 3). Thus, making an incision at the base of the cutting promotes root growth in pomegranate tree cuttings. According to Biasi et al. (2000), cellular activity in the incision area is stimulated by an increased respiratory rate and increased levels of auxin, carbohydrates, and ethylene, resulting in the formation of roots around the incision. Becker et al. (2010), who made incisions at the base of vine cuttings, observed that the incision caused an increase in the root length of cuttings. However, Wagner Júnior et al. (2004) found that making different types of incisions at the base of blueberry plants did not affect the rooting or root development of herbaceous cuttings of four cultivars. Similarly, Gontijo et al. (2003) observed greater root growth in cuttings with one and two pairs of leaves (the greatest root length was observed in cuttings with two leaves), indicating that cutting management techniques can have different effects in different species. 
Table 3. Root length (RL), shoot fresh weight (SFW), root fresh weight (RFW), shoot dry weight (SDW), root dry weight (RDW), total dry weight (TDW) and Dickson quality index (DQI) in pomegranate seedlings 'Molar' due to the handling of stakes in the period dry the year (August-December). UFCG, Pombal-PB, 2014.

\begin{tabular}{|c|c|c|c|c|c|c|c|}
\hline \multirow{2}{*}{ Manejos* } & RL & SFW & RFW & SDW & RDW & TDW & DQI \\
\hline & $\mathrm{cm}$ & \multicolumn{6}{|c|}{-----------------------------------------g planta'-1--------------------------------- } \\
\hline M1 & $26.84 \mathrm{~b}$ & $11.02 \mathrm{c}$ & $5.42 \mathrm{~b}$ & $5.27 \mathrm{c}$ & $1.85 \mathrm{~b}$ & $7.12 \mathrm{c}$ & $0.859 \mathrm{c}$ \\
\hline M2 & $25.13 \mathrm{~b}$ & $15.40 \mathrm{~b}$ & $11.54 \mathrm{a}$ & $7.61 \mathrm{~b}$ & $3.44 \mathrm{a}$ & $11.06 \mathrm{~b}$ & $1.712 \mathrm{~b}$ \\
\hline M3 & $34.85 \mathrm{a}$ & $23.56 \mathrm{a}$ & $12.41 \mathrm{a}$ & $11.26 \mathrm{a}$ & $3.31 \mathrm{a}$ & $14.58 \mathrm{a}$ & $2.271 \mathrm{a}$ \\
\hline
\end{tabular}

Means followed by the same lower case letter in the column do not differ at $5 \%$ probability by Tukey test. * M1: Cuttings with leaves; M2: Cuttings without leafless; M3: Cuttings with leaves and incision in the stake base.

Shoot fresh weight was also higher in the M3 group (23.56 g) than in the M1 and M2 groups (11.02 $\mathrm{g}$ and $15.40 \mathrm{~g}$, respectively) (Table 3). A similar pattern was observed for shoot dry matter $(\mathrm{M} 3=11.26 \mathrm{~g}, \mathrm{M} 1=5.27 \mathrm{~g}$, and $\mathrm{M} 2=7.61 \mathrm{~g})$ (Table 3). The M3 and M2 groups did not show significant differences in the fresh and dry weight of roots; both groups showed significantly higher values than the M1 group. Divergent results were reported in acerola plants by Gontijo et al. (2003), who found that the presence of two pairs of leaves provided the highest rooting percentage, number of roots per cutting, and dry weight, whereas cuttings without leaves showed no root formation.

On the basis of the results observed for the dry weights of shoots and roots, the M3 group showed greater accumulation of total dry weight (Table 3). The M1 group showed the lowest accumulation of total dry weight for pomegranate tree seedlings, concordant with the lower vegetative growth observed under this management technique (Table 2).

The M3 group showed a higher Dickson Quality Index (2.27) than the M2 (1.71) and M1 (0.86) groups (Table 3). This index is a good indicator of seedling quality, because it incorporates the strength and balance of the distribution of the seedling's biomass. According to the criteria proposed by Hunt (1990), the higher the DQI value, the greater the quality of the seedling. The M3 treatment appeared to be the most promising technique for the production of Mollar pomegranate tree seedlings by cutting in the dry season.

The seedlings from cuttings with leaves (M2) showed the lowest stomatal conductance, compared to seedlings from the other management techniques. Reduction in stomatal conductance decreases $\mathrm{CO}_{2}$ absorption and water loss (Shimazaki et al., 2007), concordant with the behavior observed in this study, in which transpiration $\left(2.48 \mathrm{mmol} \mathrm{H}_{2} \mathrm{O} \mathrm{m}^{-2} \cdot \mathrm{s}^{-1}\right), \mathrm{CO}_{2}$ uptake rate $\left(8.16 \mu \mathrm{mol} \cdot \mathrm{m}^{-2} \cdot \mathrm{s}^{-1}\right)$, and instantaneous efficiency of carboxylation $\left(0.032\left(\mu \mathrm{mol} \cdot \mathrm{m}^{-2} \cdot \mathrm{s}\right.\right.$ $\left.\left.{ }^{1}\right) \cdot\left(\mu \mathrm{mol} \cdot \mathrm{m}^{-2} \cdot \mathrm{s}^{-1}\right)^{1}\right)$ were the lowest in the M2 group (Table 4).

In contrast, seedlings produced by cuttings without leaves, but with an incision at the base, showed higher stomatal conductance $(0.21 \mathrm{mmol}$ $\left.\mathrm{H}_{2} \mathrm{O} \mathrm{m}^{-2} \cdot \mathrm{s}^{-1}\right)$, coinciding with higher rates of $\mathrm{CO}_{2}$ uptake $\left(10.58 \mu \mathrm{mol} \cdot \mathrm{m}^{-2} \cdot \mathrm{s}^{-1}\right)$, transpiration (4.46 mmol de $\left.\mathrm{H}_{2} \mathrm{O} \mathrm{m}^{-2} \cdot \mathrm{s}^{-1}\right)$, and instantaneous efficiency of carboxylation $\left(0.045\left(\mu \mathrm{mol} \cdot \mathrm{m}^{-2} \cdot \mathrm{s}^{-1}\right)\left(\mu \mathrm{mol} \cdot \mathrm{m}^{-2} \cdot \mathrm{s}^{-1}\right)^{-1}\right)$, indicating the importance of stomatal activity in gas exchange. Lima Filho and Santos (2009) observed a reduction in gas exchange due to stomatal closure in Spondias spp. plants, after transport to a field in the dry season, resulting from a reduction in soil water availability. Thus, the reduced stomatal activity observed in M1 seedlings may be related to their poorer root development (Table 3). This decreased their ability to extract water from the external environment (substrate) to supply the transpiration demands of the shoot, given that stomatal closure is one of the major mechanisms used by plants to reduce water loss (TAIZ; ZEIGER, 2009). This mechanism probably positively influenced the M1 seedlings, which showed the highest water use efficiency $\left(3.23\left(\mu \mathrm{mol} \cdot \mathrm{m}^{-2} \cdot \mathrm{s}^{-1}\right)\left(\mathrm{mmol} \mathrm{H}_{2} \mathrm{O} \mathrm{m}^{-2} \cdot \mathrm{s}^{-1}\right)^{-1}\right)$, due to the reduction in the transpiration rate caused by stomatal closure (Table 4). 
Table 4. Internal $\mathrm{CO}_{2}$ concentration $(C i)\left(\mu \mathrm{mol} \mathrm{m} \mathrm{m}^{-2} \mathrm{~s}^{-1}\right)$, transpiration $(E)\left(\mathrm{mmol} \mathrm{de} \mathrm{H}_{2} \mathrm{O} \mathrm{m}^{-2} \mathrm{~s}^{-1}\right)$, stomatal conductance $(g s)$ (mmol de $\left.\mathrm{H}_{2} \mathrm{O} \mathrm{m}^{-2} \mathrm{~s}^{-1}\right)$, rates of $\mathrm{CO}_{2}$ uptake $(A)\left(\mu \mathrm{mol} \mathrm{m}^{-2} \mathrm{~s}^{-1}\right)$, carboxylation instantaneous efficiency $(\Phi c)$ and water use efficiency $(W U E)$ $\left[\left(\mu \mathrm{mol} \mathrm{m} \mathrm{m}^{-1}\right)\left(\mathrm{mmol} \mathrm{H}_{2} \mathrm{O} \mathrm{m}^{-2} \mathrm{~s}^{-1}\right)^{-1}\right]$ in pomegranate seedlings 'Molar' due to the handling of stakes in the period dry the year (August-December). UFCG, Pombal-PB, 2014.

\begin{tabular}{ccccccc}
\hline Manejos $^{*}$ & $C i$ & $E$ & $g s$ & $A$ & $\Phi c$ & $W U E$ \\
\hline M1 & $250.75 \mathrm{a}$ & $2.48 \mathrm{~b}$ & $0.12 \mathrm{c}$ & $8.16 \mathrm{~b}$ & $0.032 \mathrm{c}$ & $3.23 \mathrm{a}$ \\
M2 & $255.18 \mathrm{a}$ & $4.32 \mathrm{a}$ & $0.18 \mathrm{a}$ & $9.66 \mathrm{a}$ & $0.038 \mathrm{~b}$ & $2.22 \mathrm{~b}$ \\
M3 & $233.18 \mathrm{~b}$ & $4.46 \mathrm{a}$ & $0.21 \mathrm{a}$ & $10.58 \mathrm{a}$ & $0.045 \mathrm{a}$ & $2.37 \mathrm{~b}$ \\
\hline
\end{tabular}

Means followed by the same lower case letter in the column do not differ at 5\% probability by Tukey test. * M1: Cuttings with leaves; M2: Cuttings without leafless; M3: Cuttings with leaves and incision in the stake base.

The M3 seedlings showed the smallest internal $\mathrm{CO}_{2}$ concentrations $\left(233.18 \mu \mathrm{mol} \cdot \mathrm{m}^{-2} \cdot \mathrm{s}^{-1}\right)$, followed by the highest $\mathrm{CO}_{2}$ uptake rates and instantaneous efficiency of carboxylation, which may be related to the increased activity of ribulose-1,5-bisphosphate carboxylase-oxygenase (Rubisco), propelling stomatal opening to increase $\mathrm{CO}_{2}$ inflow (Machado et al., 2005), and increasing vegetative growth (Table 2). Magalhães Filho et al. (2009), evaluating the influence of substrate temperature on seedlings of Valencia orange trees, also observed a decrease in the internal $\mathrm{CO}_{2}$ concentration due to an increase in the $\mathrm{CO}_{2}$ uptake rate.

Internal $\mathrm{CO}_{2}$ concentration (Figure $4 \mathrm{~A}$ ) showed a quadratic pattern, decreasing from 70 DAP, confirming the increase in the $\mathrm{CO}_{2}$ uptake rate. This may have been related to the increased photosynthetic activity, which caused an increase in $\mathrm{CO}_{2}$ consumption by Rubisco (MACHADO et al., 2005).

An increase in stomatal conductance was observed along with this reduction in internal $\mathrm{CO}_{2}$ concentration, which may be related to the need for greater influx of $\mathrm{CO}_{2}$, which was positive from 83.59 DAP with stabilization of the internal $\mathrm{CO}_{2}$ concentration (Figures $4 \mathrm{~A}, \mathrm{C}$, and D). These results corroborate those reported by Machado et al. (2005), who stated that low $C i$ values stimulate stomatal opening to increase the influx of $\mathrm{CO}_{2}$, which tends to balance $\mathrm{CO}_{2}$ consumption and intake, maintaining nearly constant values of $\mathrm{Ci}$ (Figures 4 $\mathrm{A}$ and $\mathrm{C}$ ). Despite the fluctuations observed in the internal $\mathrm{CO}_{2}$ concentration, the values observed are in agreement with those reported for $\mathrm{C} 3$ plants (200-300 $\left.\mu \mathrm{mol} \cdot \mathrm{m}^{-2} \cdot \mathrm{s}^{-1}\right)$ (TAIZ; ZEIGER, 2009).

A linear increase was observed in the stomatal conductance of seedlings from cuttings without leaves (M2 and M3), as well as in transpiration, $\mathrm{CO}_{2}$ uptake rate, and instantaneous efficiency of carboxylation (Figures 4 B, C, D, and E).

The increased stomatal conductance may have been influenced by the reduction in intercellular $\mathrm{CO}_{2}$ concentration, as previously mentioned, due to the increased photosynthetic activity, explained by the growth spurt of $131 \%$ in height, $8.2 \%$ in cutting diameter, and $197 \%$ in number of leaves observed at $100 \mathrm{DAP}$, compared to $70 \mathrm{DAP}$. Thus, the greater potential for vegetative growth achieved by these techniques (M2 and M3) (Figure 3) may be related to increased stomatal activity and photosynthesis, contributing to the increase in $\mathrm{CO}_{2}$ uptake and instantaneous efficiency of carboxylation, since stomata regulate gas exchange (SHIMAZAKI et al., 2007). 
Figure 4. Effect of evaluation times in the variables: internal $\mathrm{CO}_{2}$ concentration $(C i)\left(\mu \mathrm{mol} \mathrm{m} \mathrm{m}^{-2} \mathrm{~s}^{-1}\right)$, transpiration (E) $\left(\mathrm{mmol} \mathrm{de} \mathrm{H}_{2} \mathrm{O} \mathrm{m}^{-2} \mathrm{~s}^{-1}\right)$, stomatal conductance $(g s)\left(\mathrm{mmol} \mathrm{de} \mathrm{H}_{2} \mathrm{O} \mathrm{m}^{-2} \mathrm{~s}^{-1}\right)$, rates of $\mathrm{CO}_{2}$ uptake $(A)\left(\mu \mathrm{mol} \mathrm{m}^{-2} \mathrm{~s}^{-1}\right)$, carboxylation instantaneous efficiency $(\Phi c)$ and water use efficiency $(W U E)\left[\left(\mu \mathrm{mol} \mathrm{m}{ }^{-2} \mathrm{~s}^{-1}\right)\left(\mathrm{mmol} \mathrm{H}_{2} \mathrm{O} \mathrm{m}^{-2} \mathrm{~s}^{-1}\right)^{-1}\right]$ in pomegranate seedlings 'Molar' due to the handling of stakes in the period dry the year (August-December). UFCG, Pombal-PB, 2014.

A

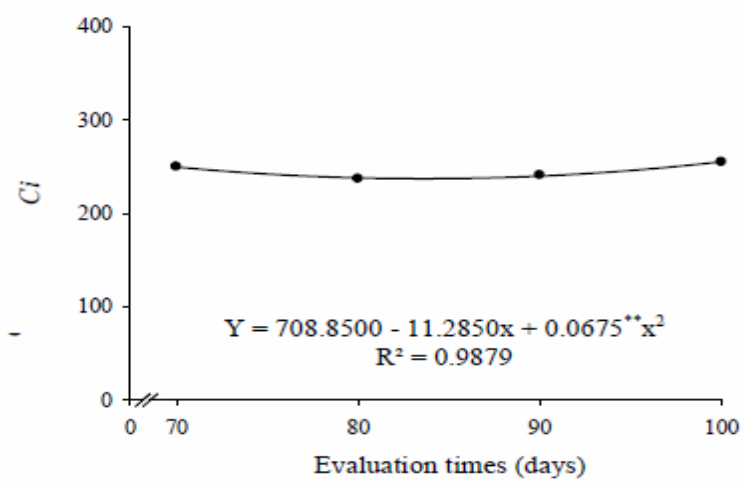

$\mathrm{C}$

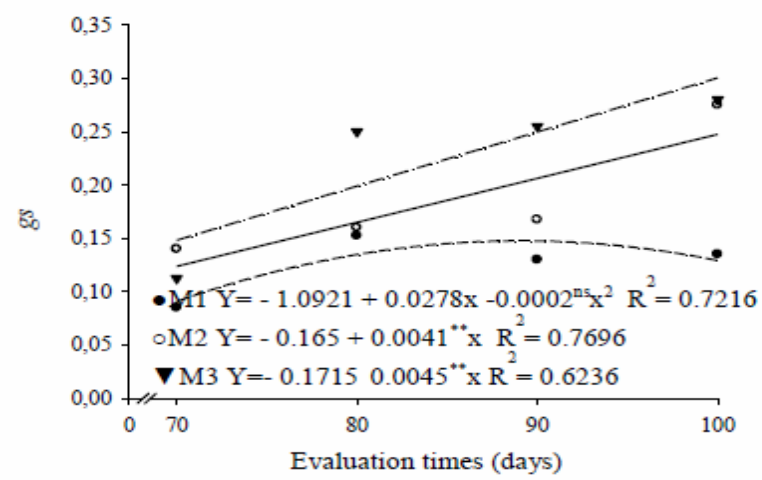

$\mathrm{E}$

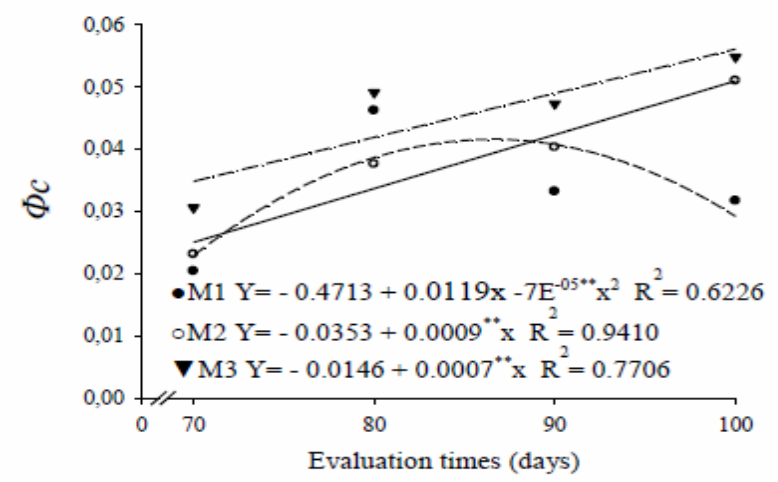

B

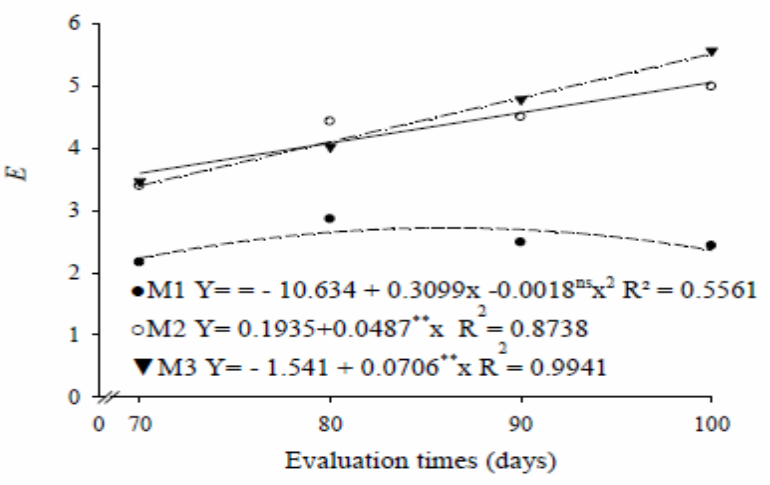

D

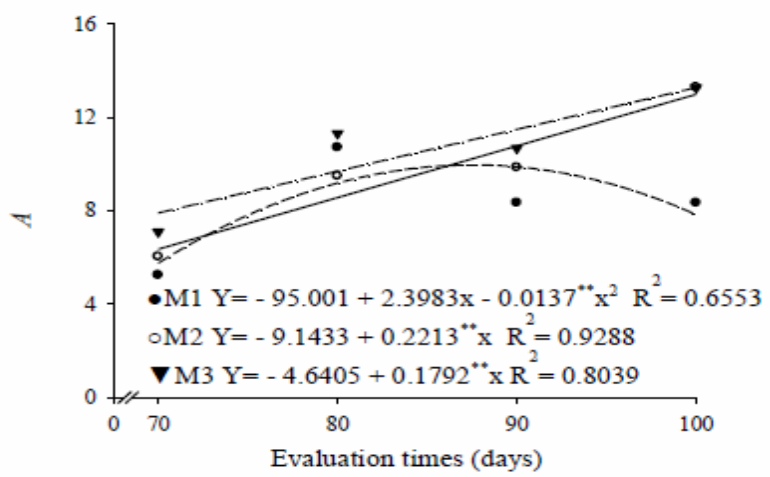

F

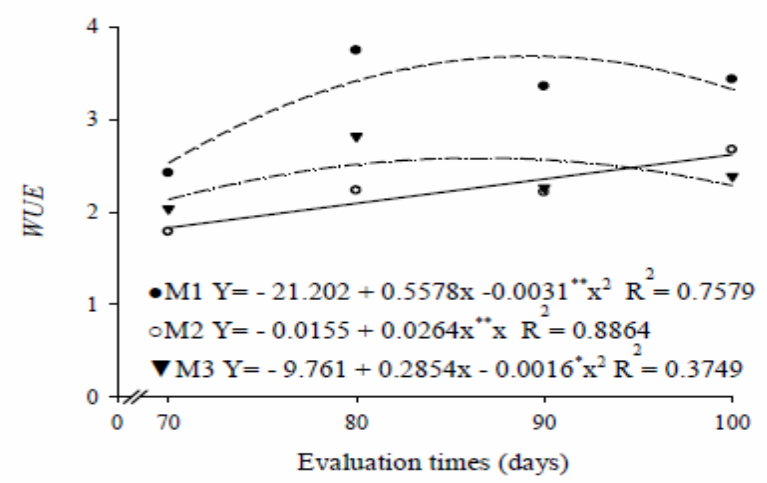

** Significant at $1 \%$ by ' $t$ ' Student test M1: Cuttings with leaves; M2: Cuttings without leafless; M3: Cuttings with leaves and incision in the stake base. 
However, seedlings from cuttings with leaves showed a quadratic pattern of $\mathrm{CO}_{2}$ uptake and instantaneous efficiency of carboxylation, which peaked at 87 and 85 DAP, respectively, decreasing thereafter (Figures $4 \mathrm{D}$ and $\mathrm{E}$ ).

Differences in water use efficiency were also observed among cutting techniques over time. However, seedlings from cuttings with leaves showed the highest water use efficiency, regardless of the time of evaluation (Figure 4 F). However, although water use efficiency reflects the amount of $\mathrm{CO}_{2}$ absorbed per unit of water lost (TAIZ; ZEIGER, 2009), these values do not show that this technique is promising, since these seedlings showed the lowest rates of $\mathrm{CO}_{2}$ uptake and carboxylation efficiency over time (Figures $4 \mathrm{D}$ and E), and the water use efficiency values may reflect the low transpiration activity observed in these plants (Figure $4 \mathrm{~B}$ ). Because a reduction in transpiration activity can be attributed to stomatal closure, which is a major mechanism for reducing water loss (TAIZ; ZEIGER, 2009), this phenomenon should have limited the photosynthetic activity of M1 and seedlings and, therefore, limited their development (Table 2).

\section{Experiment II (rainy season)}

The survival rate was greater than $40 \%$ for all techniques; however, the highest percentage was recorded in M3 (78.78\%), whereas M2 and M1 showed $66.66 \%$ and $49.99 \%$, respectively (Table 5). Bastos et al. (2009), using incision at the base of starfruit tree cuttings, obtained $29.17 \%$ survival, less than what was observed in this study. Among the factors that may have contributed to the high rates of seedling survival are the physiological, temperature, humidity, and management conditions to which the seedlings were subjected at the time of planting.

Table 5. Survival percentage (SR), number of shoots (NS), number of leaves (LN), cutting diameter (DC) and shoot length (SL) in pomegranate seedlings 'Molar' due to the handling of stakes in the rainy season of the year (January June). UFCG, Pombal-PB, 2014.

\begin{tabular}{cccccc}
\hline Manejos $(\mathrm{M})^{*}$ & SR $(\%)$ & NS & LN & DC (mm) & SL $(\mathrm{cm})$ \\
\hline M1 & $49.99 \mathrm{c}$ & $2.09 \mathrm{~b}$ & $123.17 \mathrm{~b}$ & $7.10 \mathrm{~b}$ & $24.37 \mathrm{c}$ \\
M2 & $66.66 \mathrm{~b}$ & $2.22 \mathrm{a}$ & $123.92 \mathrm{~b}$ & $7.59 \mathrm{a}$ & $32.99 \mathrm{~b}$ \\
M3 & $78.78 \mathrm{a}$ & $2.79 \mathrm{a}$ & $161.25 \mathrm{a}$ & $7.67 \mathrm{a}$ & $40.81 \mathrm{a}$ \\
\hline
\end{tabular}

Means followed by the same lower case letter in the column do not differ at $5 \%$ probability by Tukey test. * M1: Cuttings with leaves; M2: Cuttings without leafless; M3: Cuttings with leaves and incision in the stake base.

Numbers of shoots and leaves were also higher in the M3 group; the M2 and M3 groups did not differ significantly in the number of shoots, but the M3 group produced significantly more leaves than the other groups. The results obtained for the number of leaves are concordant with the results obtained for the number of shoots; the M3 group produced the highest number of shoots and, thus, a greater amount of leaves. Pandey and Bisen (2010), using the mechanical method (annealing) for propagation of pomegranate tree cuttings, also reported more leaves than the other methods. The cutting diameter (DE) did not differ between M3 and M2; however, these two groups differed from M1, which showed the smallest diameter (Table 5).

Analysis of the variables over the evaluation times showed that the highest survival rate (76.27\%) occurred at 142.23 DAP (Figure 5 A). A linear increase in the number of leaves was observed (Figure $5 \mathrm{~B}$ ); values were higher than those recorded in the dry season, when cuttings showed low numbers of emergent leaves and shoots. This may be because the evaluation period (100 days) was insufficient for this time of year, because during this period growth is slow, due to dehydration of the cuttings caused by high temperatures (Figure 1). Cutting diameter also showed a linear increase (Figure 5C). 
Figure 5. Effect of evaluation times in the variables: Survival percentage (SR), number of leaves (LN), cutting diameter (DC) and shoot length (SL) in pomegranate seedlings 'Molar' due to the handling of stakes in the rainy season of the year (January - June). UFCG, Pombal-PB, 2014.

A

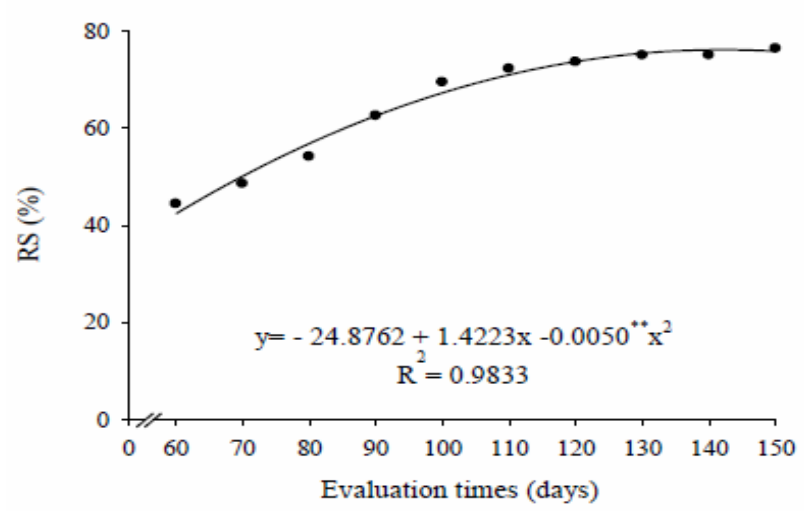

$\mathrm{C}$

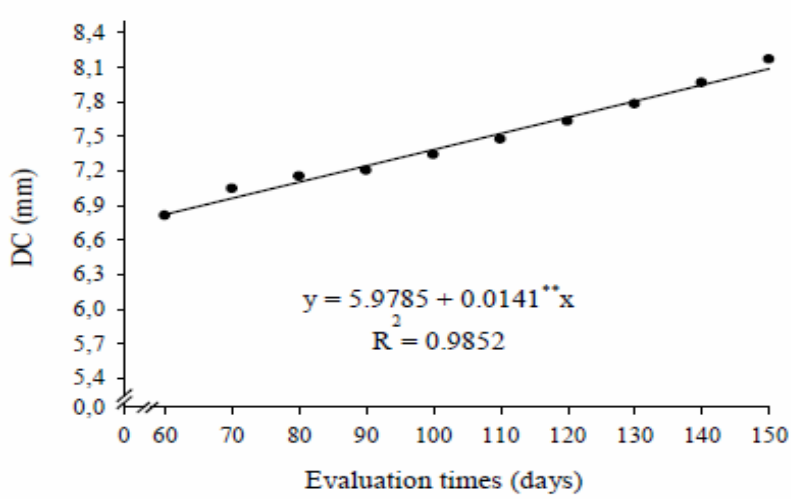

B

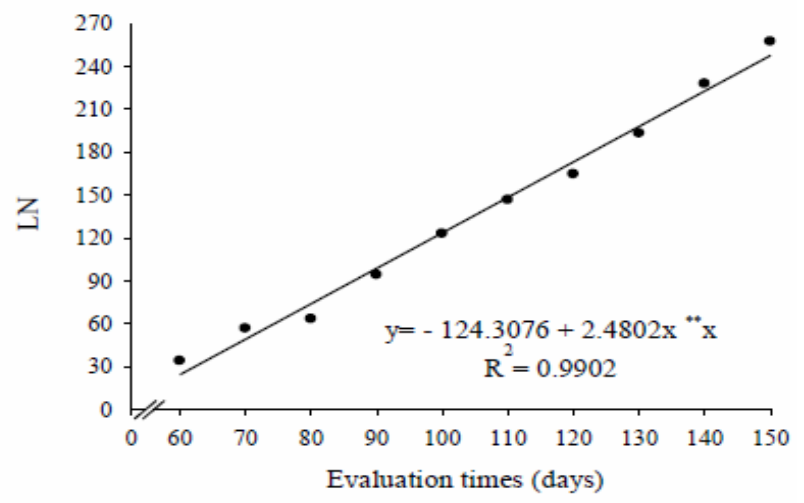

$\mathrm{D}$

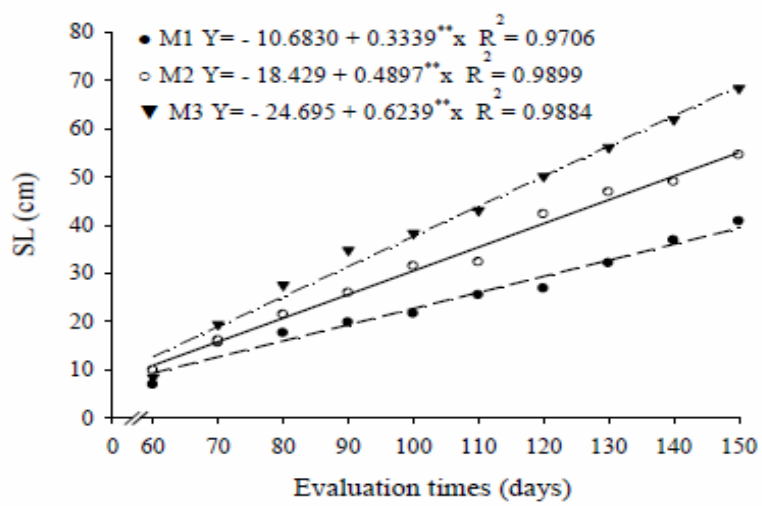

** Significant at $1 \%$ by ' $t$ ' Student test M1: Cuttings with leaves; M2: Cuttings without leafless; M3: Cuttings with leaves and incision in the stake base.

For shoot length, an interaction between cutting management and evaluation time was observed, producing a linear increase. Seedlings from M3 produced the tallest plants at $150 \mathrm{DAP}$, with an average height of $68.9 \mathrm{~cm}$; the shortest plants was observed in the M1 group $(34.4 \mathrm{~cm})$ at 150 DAP (Figure 5 D). Zietemann and Roberto (2007) observed a similar effect in guava tree seedlings, reporting a $55-\mathrm{cm}$ shoot length at 150 DAP. The data for Mollar seedling development obtained here are concordant with those reported by Marm (2010), who characterized this variety by its high vigor, rapid development, and increased productivity, among the varieties grown in Spain.
Root length was greater in cuttings without leaves with an incision at the base (M3) $(40.42 \mathrm{~cm})$; but did not differ from that of M2, with an average length of $37.32 \mathrm{~cm}$; both groups differed from the M1 group, which had an average length of 32.82 $\mathrm{cm}$ (Table 6). Thus, an incision at the base of the cutting promotes root growth in both the dry and wet seasons, although longer roots are produced in the rainy season. These results may be related to the lower atmospheric demand (temperature and air humidity) during this period, contributing to a reduction of bud abortion, reducing thermal stress, and favoring the emergence of roots and shoots (Table 5 and 6). 
Table 6. Root length (RL), shoot fresh weight (SFW), root fresh weight (RFW), shoot dry weight (SDW), root dry weight (RDW), total dry weight (TDW) and Dickson quality index (DQI) in pomegranate seedlings 'Molar' due to the handling of stakes in the rainy season of the year (January - June). UFCG, Pombal-PB, 2014.

\begin{tabular}{|c|c|c|c|c|c|c|c|}
\hline \multirow{2}{*}{ Manejos* } & RL & SFW & RFW & SDW & RDW & TDW & DQI \\
\hline & $\mathrm{cm}^{-1}$ & \multicolumn{6}{|c|}{ 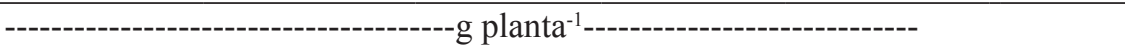 } \\
\hline M1 & $32.82 \mathrm{~b}$ & $25.27 \mathrm{~b}$ & $11.06 \mathrm{c}$ & $13.05 \mathrm{~b}$ & $5.22 \mathrm{~b}$ & $18.27 \mathrm{~b}$ & $2.35 \mathrm{a}$ \\
\hline M2 & $37.12 \mathrm{a}$ & $30.14 \mathrm{~b}$ & $13.76 \mathrm{~b}$ & $14.90 \mathrm{~b}$ & $4.51 \mathrm{c}$ & $19.42 \mathrm{~b}$ & $1.95 \mathrm{a}$ \\
\hline M3 & $40.42 \mathrm{a}$ & $38.57 \mathrm{a}$ & $15.51 \mathrm{a}$ & $19.44 \mathrm{a}$ & $6.07 \mathrm{a}$ & $25.51 \mathrm{a}$ & $2.28 \mathrm{a}$ \\
\hline
\end{tabular}

Means followed by the same lower case letter in the column do not differ at $5 \%$ probability by Tukey test. * M1: Cuttings with leaves; M2: Cuttings without leafless; M3: Cuttings with leaves and incision in the stake base.

According to Saroj et al. (2008), pomegranate tree cuttings from different varieties differ in rooting behavior. The lignin content of the tissues directly influences the rooting ability of cuttings, creating mechanical or physiological barriers. Thus, the incision at the base of the cuttings increases water absorption, thus increasing rooting efficiency, which may explain the results obtained in this study. However, the success of this technique varies with species.

Souza et al. (1995), studying rooting of hardwood cuttings of plum trees, found that an incision at the base of the cutting increased rooting by $27 \%$. Camolesi et al. (2007), studying propagation by softwood cuttings of Okinawa peach trees, observed the best results in cuttings that had undergone incision. In contrast, Wagner Júnior et al. (2004) found that different types of incisions at the base did not affect the rooting or root development of herbaceous cuttings of four blueberry cultivars (Vaccinium sp.).

Shoot fresh weight was also higher in cuttings without leaves with an incision at the base (M3), at $38.57 \mathrm{~g}$; it differed significantly from the other techniques (M1 and M2), at $25.27 \mathrm{~g}$ and $30.14 \mathrm{~g}$, respectively (Table 6). A similar behavior was observed for shoot dry weight; it was highest in M3, at $19.44 \mathrm{~g}$, and differed from the other techniques (M1 and M2), at $13.05 \mathrm{~g}$ and $14.90 \mathrm{~g}$, respectively (Table 6). The M3 group also showed better results for fresh weight $(15.51 \mathrm{~g})$ and root dry weight $(6.07 \mathrm{~g})$, which differed significantly from the other treatments (Table 6). These results corroborate those observed for the length of the root system, where the M3 technique favored higher root development, therefore promoting accumulation of fresh weight and dry weight. However, Santoro et al. (2010) reported that the best results for average fresh and dry weights of roots in guava cuttings, propagated with and without leaves, were found in cuttings with one pair of whole leaves. The cuttings without leaves showed no root formation, resulting in seedling death.

Higher accumulation of total dry mass was observed for seedlings grown from cuttings without further incision leaves at the base, due to the higher dry weight accumulation of the shoot and root (Table 6). The higher accumulation of dry weight in the M3 group may also have been related to the higher vegetative growth observed for the seedlings propagated using this management technique (Table 5).

The Dickson Quality Index was not significantly affected by the management techniques, indicating that despite the differing opinions on the techniques, they provided quality seedlings in the rainy season (Table 6), possibly due to the lower atmospheric demand (temperature and air humidity) compared to the dry period, reducing the thermal stress on the plant, so as not to compromise the development of the root systems of the seedlings. Similar results have been reported in the literature. Freitas et al. (2013) obtained a quality index of 3.1 in seedlings of custard apple and Soares et al. (2007) reported a quality index of 1.7 in soursop tree seedlings. 
Concordant with the results for vegetative growth, the highest values for gas exchange were observed when plants were propagated without leaves (M2 and M3) (Table 7). The highest rates of net uptake and instantaneous efficiency of carboxylation were observed for these techniques, indicating higher photosynthetic efficiency, as these results corroborate the lowest internal $\mathrm{CO}_{2}$ concentrations, suggesting higher activity of Rubisco, since it serves as a substrate for its operation (MACHADO et al., 2005). In plants propagated by cuttings without leaves, higher transpiration was also observed, due to the higher stomatal activity, perhaps to increase the influx of $\mathrm{CO}_{2}$. However, this increase in the transpiration rate did not decrease the water use efficiency, since the plants continued to show the highest $\mathrm{CO}_{2}$ uptake rates.

Tabela 7. Internal $\mathrm{CO}_{2}$ concentration $(C i)\left(\mu \mathrm{mol} \mathrm{m}^{-2} \mathrm{~s}^{-1}\right)$, transpiration $(E)\left(\mathrm{mmol} \mathrm{de} \mathrm{H}_{2} \mathrm{O} \mathrm{m}^{-2} \mathrm{~s}^{-1}\right)$, stomatal conductance $(g s)\left(\mathrm{mmol} \mathrm{de} \mathrm{H}_{2} \mathrm{O} \mathrm{m}^{-2} \mathrm{~s}^{-1}\right)$, rates of $\mathrm{CO}_{2}$ uptake $(A)\left(\mu \mathrm{mol} \mathrm{m}^{-2} \mathrm{~s}^{-1}\right)$, carboxylation instantaneous efficiency $(\Phi c)$ and water use efficiency $($ WUE $)\left[\left(\mu \mathrm{mol} \mathrm{m}^{-2} \mathrm{~s}^{-1}\right)\left(\mathrm{mmol} \mathrm{H}_{2} \mathrm{O} \mathrm{m}^{-2} \mathrm{~s}^{-1}\right)^{-1}\right]$ in pomegranate seedlings 'Molar' due to the handling of stakes in the rainy season of the year (January - June). UFCG, Pombal-PB, 2014.

\begin{tabular}{ccccccc}
\hline Manejos $^{*}$ & $C i$ & $E$ & $g S$ & $A$ & $\Phi c$ & $W U E$ \\
\hline M1 & $257.95 \mathrm{a}$ & $2.06 \mathrm{~b}$ & $0.10 \mathrm{~b}$ & $7.20 \mathrm{~b}$ & $0.028 \mathrm{~b}$ & $3.53 \mathrm{a}$ \\
M2 & $241.45 \mathrm{~b}$ & $2.56 \mathrm{a}$ & $0.12 \mathrm{a}$ & $7.74 \mathrm{ab}$ & $0.032 \mathrm{a}$ & $3.13 \mathrm{~b}$ \\
M3 & $236.45 \mathrm{~b}$ & $2.50 \mathrm{a}$ & $0.12 \mathrm{a}$ & $8.10 \mathrm{a}$ & $0.034 \mathrm{a}$ & $3.48 \mathrm{a}$ \\
\hline
\end{tabular}

Means followed by the same lower case letter in the column do not differ at $5 \%$ probability by Tukey test. * M1: Cuttings with leaves; M2: Cuttings without leafless; M3: Cuttings with leaves and incision in the stake base.

At 90 DAP, gas exchange values peaked (Figure 6), concordant with the results obtained in the first experiment, in which the plants had the highest value of photosynthesis between 90 and 100 DAP (Figure 4). Thus, it appears that the photosynthetic activity of pomegranate tree seedlings peaks close to $90 \mathrm{DAP}$, considering that photosynthetic activity subsequently decreased (Figure 6), which may be related to vegetative rest due to the maturity of the plant tissues.

It is noteworthy that the rate of photosynthesis decreased until 129.5 DAP, but that photosynthetic activity resumed thereafter (Figure 6 D). This recovery was also reflected in the transpiration rate, stomatal conductance, instantaneous carboxylation efficiency, and water use efficiency (Figure 6).

This resumption of photosynthetic activity can be considered to indicate the ideal time for transplanting seedlings (130 DAP), given that the plant has already passed through its vegetative rest and resumed its field growth potential. At 130 DAP, the pomegranate tree seedlings had reached an average height of approximately $45 \mathrm{~cm}(\mathrm{M} 1=$ $32.72 ; \mathrm{M} 2=45.24 ; \mathrm{M} 3=56.41 \mathrm{~cm})$, which could be used as an ideal height for transplanting seedlings of Mollar pomegranate trees (Figure 5D). 
Figure 6. Effect of evaluation times in the variables: internal $\mathrm{CO}_{2}$ concentration $(C i)\left(\mu \mathrm{mol} \mathrm{m} \mathrm{m}^{-2} \mathrm{~s}^{-1}\right)$, transpiration (E) (mmol de $\left.\mathrm{H}_{2} \mathrm{O} \mathrm{m}^{-2} \mathrm{~s}^{-1}\right)$, stomatal conductance $(g s)\left(\mathrm{mmol} \mathrm{de} \mathrm{H}_{2} \mathrm{O} \mathrm{m}^{-2} \mathrm{~s}^{-1}\right)$, rates of $\mathrm{CO}_{2}$ uptake $(A)\left(\mu \mathrm{mol} \mathrm{m}^{-2} \mathrm{~s}^{-1}\right)$, carboxylation instantaneous efficiency $(\Phi c)$ and water use efficiency $(W U E)\left[\left(\mu \mathrm{mol} \mathrm{m} \mathrm{s}^{-2} \mathrm{~s}^{-1}\right)\left(\mathrm{mmol} \mathrm{H}_{2} \mathrm{O} \mathrm{m}^{-2} \mathrm{~s}^{-1}\right)^{-1}\right]$ in pomegranate seedlings 'Molar' due to the handling of stakes in the rainy season of the year (January - June). UFCG, Pombal-PB, 2014.

A

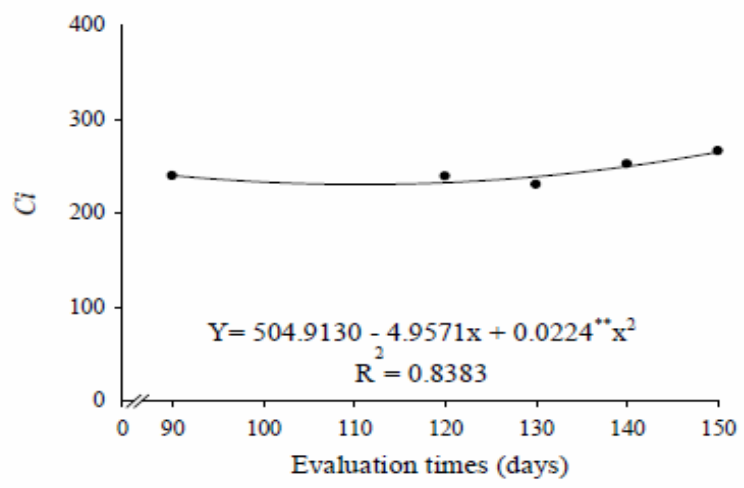

$\mathrm{C}$

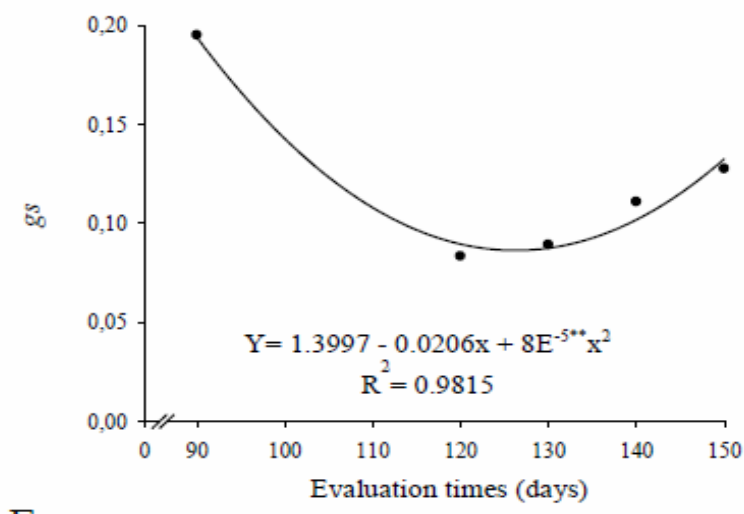

$\mathrm{E}$

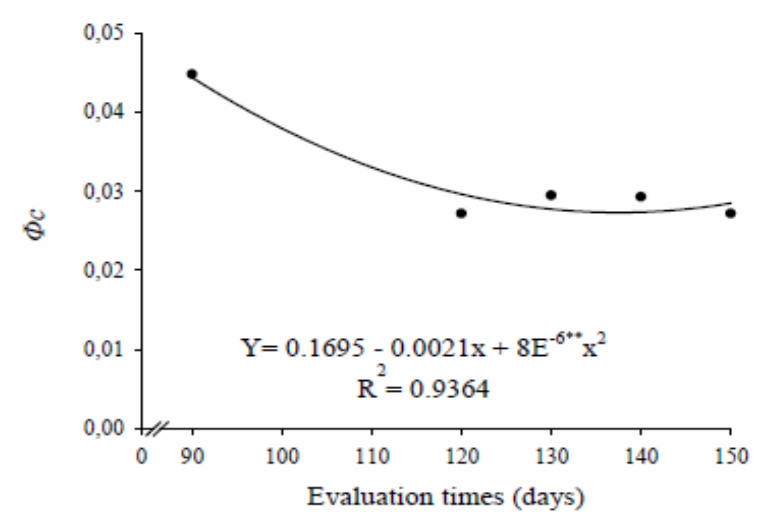

B

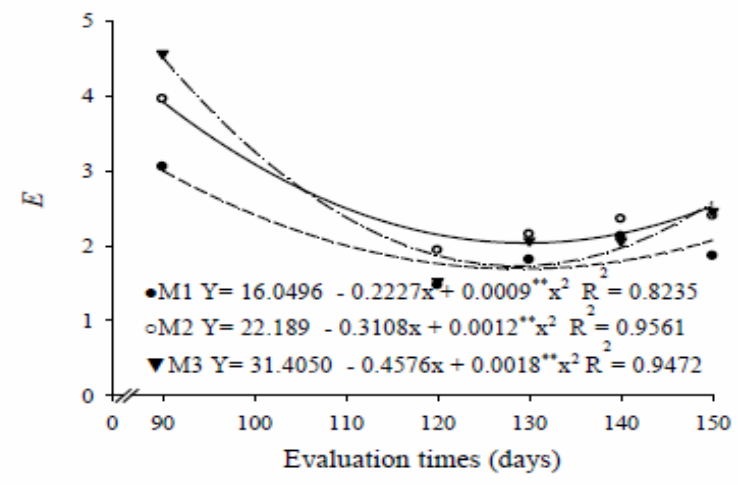

$\mathrm{D}$

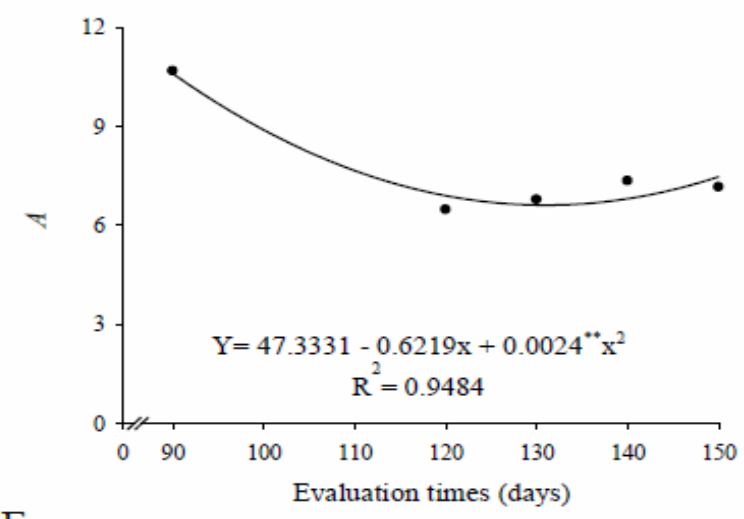

F

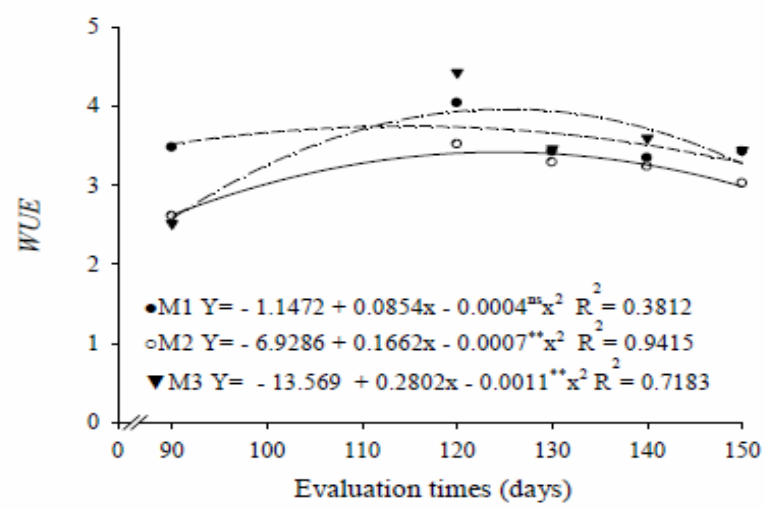

* Significant at $1 \%$ by ' $t$ ' Student test M1: Cuttings with leaves; M2: Cuttings without leafless; M3: Cuttings with leaves and incision in the stake base. 


\section{Conclusions}

Cuttings without leaves with an incision at the base are most suitable for the vegetative propagation of the Mollar variety of pomegranate tree, regardless of the time of year.

During the rainy season, the survival rate is higher, and plants are stronger, with better root and shoot development and larger amounts of root and shoot dry matter.

The use of cuttings with leaves for the vegetative propagation of Mollar variety pomegranate trees during the dry season is not feasible.

The best time for transplanting Mollar pomegranate tree seedlings is at $130 \mathrm{DAP}$, when they resume their photosynthetic potential and have an average height of $45 \mathrm{~cm}$.

Seedlings originating from cuttings without leaves, but with an incision at the base show the highest efficiency of gas exchange.

\section{References}

ALTOÉ, J. A.; MARINHO, C. S.; TERRA, M. I. C.; BARROSO, D. G. Propagação de araçazeiro e goiabeira via miniestaquia de material juvenil. Bragantia, Campinas, v. 70, n. 2, p. 312-318, 2011.

BASTOS, D. C.; SCARPARE FILHO, J. A.; LIBARDI, M. N.; PIO, R. Estiolamento, incisão na base da estaca e uso do ácido indolbutírico na propagação da caramboleira por estacas lenhosas. Ciência e Agrotecnologia, Lavras, v. 33, n. 1, p. 313-318, 2009.

BATISTA, P. F.; P. F.; MAIA, S. S. S.; COELHO, M. F. B.; BENEDITO, C. P.; GUIMARÃES, I. P. Propagação vegetativa de romã em diferentes substratos. Revista Verde de Agroecologia e Desenvolvimento Sustentável, Mossoró, v. 6, n. 4, p. 96-100, 2011.

BECKER, L. E.; PIO, R.; CAMPAGNOLO, M. A.; DALASTRA, I. M.; CURI, P. N.; MOURA, P. H. A. Lesão na base e concentrações de ácido indolbutírico no enraizamento de estacas apicais de figueira 'Roxo de Valinhos'. Semina: Ciências Agrárias, Londrina, v. 31, p. 1325-1330, 2010. Suplemento 1.

BIASI, L. A.; STOLTE, R. E.; SILVA, M. F. Estaquia de ramos semilenhosos de pessegueiro e nectarina. Revista
Brasileira de Fruticultura, Jaboticabal, v. 22, n. 3, p. 421-425, dez. 2000.

BIAZATTI, M. A. Potencial de enraizamento, vigor, enxertia interespecifica e resistência a Meloidogyne enterolobii em genótipos de araçazeiros, 2013. Dissertação (Mestrado em Produção Vegetal) Universidade Estadual do Norte Fluminense Darcy Ribeiro, Campos dos Goytacazes.

CAMOLESI, M. R.; UNEMOTO, L. K.; SACHS, P. J. D.; ROBERTO, S. R.; SATO, A. J.; FARIA, A. P.; RODRIGUES, E. B.; SILVA, J. V. Enraizamento de estacas semilenhosas de pessegueiro "Okanawa" sob efeito de lesão na base e ácido indolbutírico. Ciência Rural, Santa Maria, v. 37, n. 6, p. 180-188, 2007.

CHAGAS, E. A.; PIO, R.; BETTIOL NETO, J. E.; SOBIERAJSKI， G. R.; DALL'ORTO, F. A. C.; SIGNORINI, G. Enraizamento de estacas lenhosas de pessegueiro e clones de umezeiros submetidos à aplicação de AIB. Ciência e Agrotecnologia, Lavras, v. 32, n. 3, p. 986-991, 2008.

CRUZ, C. A. F.; PAIVA, H. N.; GUERRERO, C. R. A. Efeito da adubação nitrogenada na produção de mudas de sete-cascas (Samanea inopinata (harms) ducke). Revista Árvore, Viçosa, MG, v. 30, n. 4, p. 537-546, 2006.

FERREIRA, D. F. Sisvar: a computer statistical analysis system. Ciência e Agrotecnologia, Lavras, v. 35, n. 6, p. 1039-1042, 2011.

FREITAS, R. M. O.; NOGUEIRA, N. W.; PINTO, J. R. S.; TOSTA, M. S.; DOMBROSKI, J. L. D. Fertilizante fosfatado no desenvolvimento inicial de mudas de pinheira. Biosciences Journal, Uberlândia, v. 29, n. 2, p. 319-327, 2013.

GONTIJO, T. C. A.; RAMOS, J. D.; MENDONÇA, V.; PIO, R.; ARAUJO NETO, S. E.; CORRÊA, F. L. O. Enraizamento de diferentes tipos de estacas de aceroleira utilizando ácido indolbutírico. Revista Brasileira de Fruticultura, Jaboticabal, v. 25, n. 2, p. 290-292, 2003.

HUNT, G. A. Effect of styroblock design and coopertreatment on morfhology of conifer seedlings. In: TARGET SEEDLINGS SYPOSIUM, MEETING OF THE WESTERN FOREST NURSERY ASSOCIATIONS, 1990, Roseburg. Proceeding... Fort Collins: United States Department of Agriculture, Forest Service, 1990. p. 218-222.

HUSSAIN, I.; KHATTAK, A. M.; AMIN, N. U.; AMAN, F.; SAJID, M. Response of different pomegranate cuttings types to different environmental conditions. Sarhad Journal of Agriculture, Peshawar, v. 28, n. 1, p. 15-18, 2012. 
INSTITUTO BRASILEIRO DE FRUTAS - IBRAF. Retrospectiva analítica 2010 da cadeia produtiva das frutas. São Paulo: IBRAF, 2011. 202 p.

KONRAD, M. L. F.; SILVA, J. A. B.; FURLANI, P. R.; MACHADO, E. C. Trocas gasosas e fluorescência da clorofila em seis cultivares de cafeeiro sob estresse de alumínio. Bragantia, Campinas, v. 64, n. 3, p. 339-347, 2005.

LIMA FILHO, J. M. P.; SANTOS, C. A. F. Avaliações fenotípicas e fisiológicas de espécies de spondias tendo como porta enxerto o umbuzeiro (Spondias tuberosa Cam.). Revista Caatinga, Mossoró, v. 22, n. 1, p. 59-63, 2009.

MACHADO, E. C.; SCHMIDT, P. T.; MEDINA, C. L.; RIBEIRO, R. V. Respostas da fotossíntese de três espécies de citros a fatores ambientais. Pesquisa Agropecuária Brasileira, Brasília, v. 40, n. 12, p. 1161-1170, 2005.

MAGAlHÃES FILHO, J. R.; MACHADO, E. C.; MACHADO, D. F. S. P.; RAMOS, R. A.; RIBEIRO, R. V. Variação da temperatura do substrato e fotossíntese em mudas de laranjeira 'Valência'. Pesquisa Agropecuária Brasileira, Brasília, v. 44, n. 9, p. 1118-1126, 2009.

MINISTERIO DE MEDIO AMBIENTE Y MEDIO RURAL Y MARINO - MARM. Anuário de estatística. Madrid: Catálogo General de Publicaciones Oficiales, 2010.

PANDEY, S. K.; BISEN, A. Effect of mechanical treatments on rooting in cuttings of guava, lemon and pomegranate. Journal of Horticulture and Forestry, Jabalpur, v. 2, n. 5, p. 95-98, may 2010.

PIO, R.; DALL'ORTO, F. A. C.; ALVARENGA, A. A.; ABRAHÃO, E.; CHAGAS, E. A.; SIGNORINI, G. Propagação do marmeleiro 'Japonês' por estaquia e alporquia realizadas em diferentes épocas. Ciência $e$ Agrotecnologia, Lavras, v. 31, n. 2, p. 570-574, 2007.

PRADO, R. M.; VALE, D. W.; ROMUALDO, L. M. Fósforo na nutrição e produção de mudas de maracujazeiro. Acta Scientiarum Agronomy, Maringá, v. 27, n. 3, p. 493-498, 2005.

RAMOS, D. P.; LEONEL, S.; DAMATTO JÚNIOR, E. R. Avaliação da época de estaquia e uso de bioregulador no enraizamento de estacas de figueira. Revista Brasileira de Fruticultura, Jaboticabal, v. 30, n. 3, p. 748-753, 2008.
SANTORO, P. H.; MIKAMI, A. Y.; SOUZA, S. G. H.; ROBERTO, S. R. Influência de folhas e lesões na base de estacas herbáceas no enraizamento de goiabeira da seleção 8501-9. Semina: Ciências Agrárias, Londrina, v. 31, n. 2, p. 289-294, 2010.

SAROJ, P. L.; AWASTHI, O. P.; BHARGAVA, R.; SINGH, U. V. Standardization of pomegranate propagation by cutting under mist system in hot arid region. Indian Journal of Horticulture, New Delhi, v. 65, n. 1, p. 243-250, 2008.

SCALOPPI JÚNIOR, E. J.; MARTINS, A. B. G. Clonagem de quatro espécies de Annonaceae potenciais como porta-enxertos. Revista Brasileira de Fruticultura, Jaboticabal, v. 25, n. 2, p. 286-289, 2003.

SHIMAZAKI, K. I.; DOI, M.; ASMANN, S. M.; KINOSHITA, T. Light regulation of stomatal movement. Annual Review of Plant Biology, Palo Alto, v. 58, n. 1, p. 219-247, 2007.

SOARES, I.; LIMA, S. C.; CRISÓSTOMO, L. A. Crescimento e composição mineral de mudas de gravioleira em resposta a doses de fósforo. Revista Ciência Agronômica, Fortaleza, v. 38, n. 4, p. 343-349, 2007.

SOUZA, C.; NACHTIGAL, J. C.; KERSTEN, E. Efeito da lesão e do ácido indolbutírico no enraizamento de duas cultivares de ameixeira (Prunus salicina, lindl) através de estaca. Revista Brasileira de Agrociência, Pelotas, v. 1, n. 3, p. 171-174, 1995.

TAIZ, L.; ZEIGER, E. Fisiologia vegetal. Porto Alegre: Artmed, 2009. 819 p.

VIDAL, L. H. I.; SOUZA, J. R. P.; FONSECA, E. P.; BORDIN, I. Qualidade de mudas de guaco produzidas por estaquia em casca de arroz carbonizada com vermicomposto. Horticultura Brasileira, Vitória da Conquista, v. 24, n. 1, p. 26-30, 2006.

WAGNER JÚNIOR, A.; COUTO, M.; RASEIRA, M. C. B.; FRANZON, R. C. Efeito da lesão basal e do ácido indolbutírico no enraizamento de estacas herbáceas de quatro cultivares de mirtilo. Revista Brasileira de Agrociência, Pelotas, v. 10, n. 2, p. 251-253, 2004.

ZIETEMANN, C.; ROBERTO, S. R. Produção de mudas de goiabeira (psidium guajava L.) em diferentes substratos. Revista Brasileira de Fruticultura, Jaboticabal, v. 29, n. 1, p. 137-142, 2007. 
